\title{
Discussion: Critical assessment of evidence related to the 1989 Hillsborough Stadium disaster, UK
}

\author{
James Frank Dickie BSc, PhD, MIStructE \\ Crowdsafe Ltd, Altrincham, UK (corresponding author: \\ crowdsafe@btinternet.com)
}

\section{Contribution by B. Reid}

The contributor is grateful to Dr Dickie for writing the paper on the Hillsborough terraces as they existed at the time of the 1989 disaster (Dickie, 2018). Due to his extensive track record in studying and experimenting with crowd pressures, he has unique and unrivalled experience and expertise in the subject. In his paper, Dr Dickie identifies three major deficiencies relating to the terrace barriers at Hillsborough. These are

- the layout of the barriers

v the height of at least one barrier

n the strength of the barriers.

All of these issues were non-compliant with the Guide to Safety at Sports Grounds (Green Guide) that was current at the time (Home Office, 1986). Together, these three issues had a primary role in generating the extent of the tragic loss of life that occurred.

From the contributor's personal experience with stadium design, he agrees with the statement made by Mr John Cutlack when giving expert evidence to the most recent inquest that some of the seeds of the disaster were sown in 1979. The contributor would supplement, however, the list of issues discussed by Dr Dickie by adding the presence of both front and radial fences that created the pens. The pens, from which there was no available escape for the occupants, should have been an obvious danger to those designing, licensing and running the ground for sports use. In this regard, Dr Sam Thorburn had raised concerns on this issue. In 1986, at the 17th national seminar held by the Sports Council at Harrogate, the proceedings record that he said, 'the provision of a high security fence between the spectators and the playing surface prevents both the exercising of control over crowd misbehaviour and the egress of spectators at a time of panic or disaster. The use of fences to restrict crowd movement in a cage environment is not the best solution' (Thorburn, 1986: p. 33). This advice, given 3 years before the Hillsborough disaster, did not receive recognition from football authorities.

Following the Ibrox Stadium disaster in 1971, the technical support group to Lord Wheatley's inquiry stated, 'this report recommends guidelines which are based on the latest knowledge available, taking into account research and common usage which has so far proved to be safe' (Wheatley, 1972: p. 21). The concept that common usage which has so far proved to be safe was, in the contributor's
William Mitchell Reid BSc, CEng, FREng, FICE, FIStructE WMR Consultancy, Motherwell, UK

opinion, as flawed a concept then as it is now and whatever part this may have played by those designing, licensing and using the Hillsborough stadium was a false basis to assess safety.

In the contributor's opinion, there is a commonality between most major disasters involving loss of life. For example, Ronan Point, Grenfell Tower and Hillsborough all had aspects where common usage had given those with a duty of care false confidence to accept that the respective constructions were safe. All resulted in loss of life due to a trigger incident that had not been considered in sufficient detail, or at all, by those responsible for design and certification. At Ronan Point, the trigger event was a gas explosion in one of the flats that resulted in progressive collapse of the inadequately tied precast concrete panel structure; at Grenfell Tower, the trigger event appears to have been a fire in one of the flats that ignited cladding with inadequate fire resistance; and at Hillsborough, the trigger event was the opening of a gate that allowed football fans to overcrowd pens 3 and 4. All three examples were 'disasters waiting to happen' but, at least to some extent, were considered safe due to previous usage. In the contributor's opinion, the primary fault lay with those who created the flawed constructions and failed to realise the inherent dangers, rather than with those who unwittingly activated the triggers.

\section{Author's reply}

Bill Reid's reference to other disasters adds considerably to the issues raised in this paper.

Reference is made to the use of the phrase 'common usage which has so far proved to have been safe'. This phrase or like terminology is frequently used today where measures to improve safety are promoted that conflict with the commercial interests.

An accident rarely occurs as a consequence of a single action. A chain of events can be found leading up to the accident. While it may be convenient to identify one factor as the cause of the accident, this is simplistic.

The number of fatalities in the Ronan Point disaster that Reid makes reference to was low. However, this was simply fortuitous due to the time of day that the gas explosion occurred, which resulted in the domino collapse of structural elements. The trigger for the collapse was an event in one room. The recent Grenfell Tower catastrophe referred to has similarities in that again the trigger for the fire was an 
event in one room. As Reid correctly states in both cases, the individual who triggered the event did so unwittingly.

The 1971 Ibrox disaster referred to by Reid and the 1989 Hillsborough disaster have a common flaw that does not allow for the use of the word 'unwittingly'.

Consider the 1971 Ibrox disaster. In 1961 two deaths occurred on the same exit stairway on which 66 deaths occurred in 1971. The Wheatley inquiry following the 1971 disaster found the club complacent in its attitude to previous problems there. The technical evidence provided to that inquiry provided the basis for the first edition of the Guide to Safety at Sports Grounds (Home Office, 1976), commonly referred to as the Green Guide. The sixth edition of this guide was published recently (Home Office, 2018). The value of this document has achieved worldwide recognition in the provision of definitive advice for spectator safety.

Consider the 1989 Hillsborough disaster. In 1981 the crowd crushing that occurred on the same terracing during the Tottenham against Wolves semi-final resulted in broken arms, legs and ribs and 38 persons being treated in hospital or by the St John Ambulance Brigade. Remedial measures taken following the incident did not accord with the recommendations of the Guide to Safety at Sports Grounds. Failure to understand the recommendations of the guide were apparent at the Taylor inquiry that followed the disaster.

Regarding perimeter fences, the final report of the Taylor inquiry recommended a maximum height should a perimeter fence be in place but did not recommend that there must be such fencing.

Those clubs which presently have no perimeter fencing may well consider it safe to continue that way (Home Office, 1990: p. 32).

A comparison is made within this author's paper of the number of fatalities in similar areas of the terrace where the crowd densities on both were considered to be essentially the same (Dickie, 2018: p. 58).

The arrangement in pen 3 provided $44 \%$ of Green Guide recommendations with regard to barrier height and layout compared with $59 \%$ in pen 4.

Less than $20 \%$ of the fatalities are considered to have occurred in pen 4. While it appears paradoxical, on a correctly designed terrace, an increasing density does not necessarily result in increased forces within the crowd. The extent of lean within a crowd on a terrace dictates the level of force experienced by individual spectators.

The failures, by the parties involved, to recognise and address properly the flaws in the terrace as revealed in the 1981 incident are, in this author's opinion, more significant than accepting the trigger for the catastrophe as the obvious reason as opposed to simply the initiating event.

\section{REFERENCES}

Dickie JF (2018) Critical assessment of evidence related to the 1989 Hillsborough Stadium disaster, UK. Proceedings of the Institution of Civil Engineers - Forensic Engineering 171(2): 58-69, https://doi.org/ 10.1680/jfoen.18.00007.

Home Office (1976) Guide to Safety at Sports Grounds, 1st edn. Her Majesty's Stationery Office, London, UK.

Home Office (1986) Guide to Safety at Sports Grounds, 2nd edn. Her Majesty's Stationery Office, London, UK.

Home Office (1990) The Hillsborough Stadium Disaster: The Final Report. Her Majesty's Stationery Office, London, UK, Command Paper 962, pp. 32.

Home Office (2018) Guide to Safety at Sports Grounds, 6th edn. Her Majesty's Stationery Office, London, UK.

Thorburn S (1986) The way forward: structures for new stadia developments. In Proceedings of the 17th National Seminar and Exhibition, Harrogate, UK, 25-27 February. The Sports Council, London, UK, p. 33.

Wheatley J (1972) Report of the Inquiry into Crowd Safety at Sportsgrounds. Her Majesty's Stationery Office, London, UK.

\section{How can you contribute?}

To discuss this paper, please email up to 500 words to the editor at journals@ice.org.uk. Your contribution will be forwarded to the author(s) for a reply and, if considered appropriate by the editorial board, it will be published as discussion in a future issue of the journal.

Proceedings journals rely entirely on contributions from the civil engineering profession (and allied disciplines). Information about how to submit your paper online is available at www.icevirtuallibrary.com/page/authors, where you will also find detailed author guidelines. 